\title{
Non-Thermal High Pressure Processing, Pulsed Electric Fields and Ultrasound Preservation of Five Different Table Wines
}

\author{
Sanelle van Wyk ${ }^{1}$, Lewis Hong ${ }^{1}$ and Filipa V. M. Silva ${ }^{2, *(D)}$ \\ 1 Department of Chemical \& Materials Engineering, University of Auckland, Private Bag 92019, Auckland 1142, \\ New Zealand; sanellevanwyk@yahoo.com (S.v.W.); shon605@aucklanduni.ac.nz (L.H.) \\ 2 LEAF-Linking Landscape, Environment, Agriculture and Food, Associated Laboratory TERRA, Instituto \\ Superior de Agronomia, Universidade de Lisboa, Tapada da Ajuda, 1349-017 Lisboa, Portugal \\ * Correspondence: fvsilva@isa.ulisboa.pt
}

check for updates

Citation: van Wyk, S.; Hong, L.; Silva, F.V.M. Non-Thermal High Pressure Processing, Pulsed Electric Fields and Ultrasound Preservation of Five Different Table Wines. Beverages 2021, 7, 69. https:/ / doi.org/10.3390/beverages7040069

Academic Editors: José Sousa

Câmara, Stamatina Kallithraka and Matteo Marangon

Received: 9 August 2021

Accepted: 8 October 2021

Published: 11 October 2021

Publisher's Note: MDPI stays neutral with regard to jurisdictional claims in published maps and institutional affiliations.

Copyright: (c) 2021 by the authors. Licensee MDPI, Basel, Switzerland. This article is an open access article distributed under the terms and conditions of the Creative Commons Attribution (CC BY) license (https:// creativecommons.org/licenses/by/ $4.0 /)$.

\begin{abstract}
Wine preservation by alternative non-thermal and physical methods including high pressure processing (HPP), pulsed electric fields (PEF) and power ultrasound (US) technologies was investigated. The effect of these technologies on some quality parameters of five table wines was determined directly after processing and two months storage. For each wine, the $\mathrm{pH}$, colour density, total phenolic content and antioxidant activity quality parameters were determined and the different treatments were compared. The $\mathrm{pH}$ of the untreated and treated wines generally remained unchanged after processing and storage. The antioxidant activity of the wines decreased after processing and storage. Generally, non-thermal processing did not affect the wine quality parameters during the 2 months storage. Overall, this study demonstrated that HPP had the smallest effect on the quality parameters assessed in five different wines.
\end{abstract}

Keywords: pasteurization; HPP; PEF; US; storage; quality; antioxidant activity; total phenolic content; colour

\section{Introduction}

Table wines typically have alcohol contents ranging between 9 and 15\% $v / v$ [1]. To maintain the original wine quality, the recommended storage temperature for red, Rosé and white wines are 14 to $18{ }^{\circ} \mathrm{C}, 10$ to $12{ }^{\circ} \mathrm{C}$ and 8 to $12{ }^{\circ} \mathrm{C}$, respectively [2]. Typical red wines can be stored unopened for 2 to 3 years, while under stable temperatures fine red wines can be stored for decades. The quality of some red wines can be improved during storage with the formation of specific and desirable flavours and compounds. This is often referred to as wine ageing. On the contrary, the quality of white wines, osé and several commercial red wines typically do not improve during storage. Thus these wines should be sold as soon as they are produced and stored no more than 1 to 2 years. Wine quality can deteriorate during storage due to exposure to sunlight, high temperatures, microbial spoilage and the failure of bottle closures. The shelf life of wines depends on the type of wine and preferences of the consumer [3]. On average, red wines have a shelf life of up to five years, which is significantly longer than the shelf life of white wines. During storage, the colour of red wines change from the purplish tone of young wines to the more stable brick-like shade of matured wines [3-5]. Temperatures below $25^{\circ} \mathrm{C}$ help retain fresh and fruity characteristics while temperatures above $40{ }^{\circ} \mathrm{C}$ leads to the rapid deterioration of wine quality. These high temperatures promote Maillard and thermal degradation reactions leading to undesirable flavours, sedimentation and brown coloured wine [3,6].

Non-thermal food preservation technologies such as high pressure processing (HPP), pulsed electric fields (PEF) and power ultrasound (US) have the potential to extend wine shelf life by inactivating undesirable microorganisms with minimal impact on wine sensory properties. In a previous study by Van Wyk et al. (2018) two triangle tests were carried out by 28 experienced assessors who demonstrated no significant differences in Cabernet 
Sauvignon red wine overall aroma and palate between: (i) HPP (400 MPa, 5 s) treated wine and untreated wine after 1 year storage at $25^{\circ} \mathrm{C}$; (ii) PEF $(46.8 \mathrm{kV} / \mathrm{cm}, 100 \mathrm{~Hz}, 20.5 \mu \mathrm{s}$ treatment time) treated wine and untreated wine after 1 year storage at $25^{\circ} \mathrm{C}$ [7].

HPP is a batch process that relies on the application of uniform pressures of 100 to $600 \mathrm{MPa}$ to beverages and foods. It has been used to inactivate spoilage microorganisms, namely yeasts and moulds in fruit juices, beer and wine [8-13]. Since 2000, the usage of HPP technology worldwide has increased exponentially and is now being implemented commercially in Japan, USA, Europe and Oceania. It is estimated that the number of HPP units installed in industry worldwide exceeded 350 in 2015, with a global food market value of $\$ 9.8$ bn US. HPP processed products available include fruit and vegetables, beverages, juices, pre-cooked meals and meat- and fish-based products $[14,15]$.

PEF inactivate spoilage yeasts and bacteria in wine and other foods through the application of short, high electric field strength pulses which causes the electroporation of microbial cell membranes [16-21]. A study found that PEF processing of red wine resulted in no quality changes in the wine properties, while ensuring microbial stability [18].

In the case of US, a technology also known as sonication or ultrasonication, a probe is submerged in direct contact with the liquid food, which causes the formation of cavitation bubbles [8,22-24]. When the bubbles burst, localized high pressure regions are created which inactivate some microbes and enzymes.

A number of studies on the effect of HPP, PEF and US on wine quality have been conducted $[7,10,18,21,25-27]$. Some studies reported changes in wine quality factors including the acceleration of wine ageing. This suggests that these non-thermal technologies have the potential to shorten the time required to produce desirable high quality 'aged' wines. However, comparisons between HPP, PEF and US's effect on the same wines and the effect of the same technology on different types of wine have not been investigated. Therefore, in this study five different table wines were processed and the main objectives were to compare the antioxidant activity, total phenolics content, colour density and $\mathrm{pH}$ quality parameters of: (i) HPP, PEF and US treated and untreated wines directly after processing and (ii) HPP, PEF and US treated and untreated wines after two months storage. Given the number of wines processed (5) and the three different treatments applied, only a preliminary evaluation of the five wines quality was carried out (four quality parameters). In future experiments the objective is to perform more detailed quality analyses for those wines which showed differences in the basic quality parameters assessed.

\section{Materials and Methods}

\subsection{Characteristics of Different Varietal Wines Processed}

To determine the impact of HPP, PEF and US on wine quality parameters directly after processing and after two months storage, five New Zealand wines recently manufactured in the same year of the experiments were purchased. These wines included a Syrah, Pinot Noir, Rosé, Sauvignon Blanc and Pinot Gris. Table 1 presents information on the grape variety, year, alcohol content and residual sugar content of the wines used in this study, as provided by the winemakers. All the wines used in this study contain $\mathrm{SO}_{2}$, which may influence the results. However, using commercial wines containing $\mathrm{SO}_{2}$ better reflects the majority of wines available on the market which can be processed with novel technologies.

Table 1. Characteristics of five table wines used in this study*.

\begin{tabular}{ccccc}
\hline Wine Grape Variety & Type & Year & Alcohol (\% v/v) & Residual Sugar (g/L) \\
\hline Sauvignon Blanc & White & 2014 & 13.0 & 4.0 \\
Pinot Gris & White & 2014 & 13.0 & 12.2 \\
Pinot Gris, Merlot, Malbec & Rosé & 2014 & 12.5 & 4.3 \\
Syrah & Red & 2014 & 13.5 & $<1.0$ \\
Pinot Noir & Red & 2014 & 13.0 & $<1.0$ \\
\hline
\end{tabular}

* Properties provided by the winemakers; alcohol concentration determined using gas chromatography (GC); residual sugar concentration determined using enzymatic assay. 


\subsection{Experimental Design}

For each of the five wines processed, at least 7 bottles of wine of the same production batch were used in the experiments: $750 \mathrm{~mL}$ was stored untreated, $1.5 \mathrm{~L}$ was processed using non-thermal $\left(<40^{\circ} \mathrm{C}\right)$ batch HPP, $1.5 \mathrm{~L}$ treated by continuous PEF and $1.5 \mathrm{~L}$ sonicated with US process, as described in Sections 2.3-2.5. Because the aim was to study the effect of the technologies in more than one wine, the number of quality parameters analyzed and corresponding volume of wine processed was limited. For each non-thermal technology, the treated wine was bottled and sealed (with an airtight screwcap) in two $750 \mathrm{~mL}$ dark glass wine bottles, similar to winery practices. The bottles were stored for two months in a walk-in refrigeration room at $15.0 \pm 1.5^{\circ} \mathrm{C}$. The antioxidant activity, total phenolic content, colour density and $\mathrm{pH}$ of the unprocessed and processed wine samples were measured directly after HPP, PEF and US treatment and after 2 months storage. The focus was placed on these wine qualities because they are frequently used in wine research to monitor the quality of wines subjected to different treatments and storage conditions.

\subsection{High Pressure Processing}

For HPP $200 \mathrm{~mL}$ wine samples were vacuum sealed in $154 \mu \mathrm{m}$ thick pouches (Caspak, Silverdale, New Zealand). The pouches consisted of polyethylene terephthalate (PET) and linear low-density polyethylene (LLDPE). Vacuum sealing was used to prevent bursting during depressurisation. The packaged wine samples were cooled to $3^{\circ} \mathrm{C}$ before high pressure treatment. A total of $1.5 \mathrm{~L}$ of each wine was processed in multiple packaged samples for further storage and quality analysis.

A QFP 2L-700 (Avure Technologies, Columbus, OH, USA) high pressure food processing system was used for the HPP treatment. The equipment includes a $2 \mathrm{~L}$ cylindrical pressure chamber, distilled water as the pressure transmitting medium, water circulation for cooling and a pumping and control system operated using the manufacturer supplied software. A HPP pressure of $600 \mathrm{MPa}$ for $5 \mathrm{~min}$ was used, as this treatment resulted in $>6 \log$ reductions of the wine spoilage yeast, Brettanomyces bruxellensis $[12,13]$. The temperature inside the pressure chamber was monitored using two internal thermocouples. Non-thermal conditions were maintained throughout processing with a temperature $<40{ }^{\circ} \mathrm{C}$. After processing, the wines were transferred to two clean $750 \mathrm{~mL}$ glass wine bottles and sealed for storage.

\subsection{Pulsed Electric Field}

The PEF unit used in this study was designed and built in the University of Auckland [28]. It consists of a high voltage pulse generator, treatment chamber, data collection, fluid managing system and a cooling system. Square bipolar pulses with a pulse width of $1.5 \mu \mathrm{s}$ and frequencies up to $1 \mathrm{kHz}$ can be produced with voltages up to $30 \mathrm{kV}$ using the pulse generator made by H. F. Power Ltd. (Auckland, New Zealand). The treatment chamber consists of a stable synthetic fluoropolymer of tetrafluoroethylene (poly-tetrafluoro ethylene) also known as Teflon. Two mesh 316 food grade stainless steel parallel electrodes ( $50 \mathrm{~mm}$ diameter, $15 \mathrm{~mm}$ between electrodes) and a narrow-designed treatment field were also used to assure a higher electric field density area. The dimensions of the treatment zone depth and diameter were 5 and $8 \mathrm{~mm}$, respectively with a total volume of the treatment chamber of $251.2 \mathrm{~mm}^{3}$ [16].

Before treatment, the wines were cooled down to $3{ }^{\circ} \mathrm{C}$ to ensure non-thermal processing conditions $\left(<40^{\circ} \mathrm{C}\right)$. The electric conductivity of the wines ranged between 0.88 and $2.04 \mathrm{mS} / \mathrm{cm}$ (Mettler Toledo SevenCompact ${ }^{\mathrm{TM}}$ conductivity meter, $22^{\circ} \mathrm{C}$ ). A total of $1.5 \mathrm{~L}$ of each wine was PEF treated in continuous mode using a flow rate of $4.3 \mathrm{~mL} / \mathrm{s}(0.058 \mathrm{~s}$ residence time), which exposed each wine to an electric field strength of $45 \mathrm{kV} / \mathrm{cm}$ and $800 \mathrm{~Hz}$ frequency, equivalent to 46 pulses and $70 \mu$ s of real treatment time. The maximum electric field strength and lowest flow rate (longest single pass treatment time) that resulted in stable square, bipolar waves with no sparks were used in all the wines. Preliminary 
results, using the same PEF conditions, achieved a 2.4 log reduction of B. bruxellensis (WLP 650 strain) in red wine $(12.9 \%$ alc. $v / v)$ [17].

\subsection{Ultrasound}

A UP200S ultrasonic processor by Hielscher (Hielscher-Ultrasonic Gmbh, Teltow, Germany) was used in this study. High frequency $(24 \mathrm{kHz})$ longitudinal vibrations were produced through electrical excitation. All wines were processed at atmospheric pressure using a $14 \mathrm{~mm}$ diameter tip sonotrode at a maximum amplitude of $125 \mu \mathrm{m}$, which delivered $105 \mathrm{~W} / \mathrm{cm}^{2}$ of acoustic energy density. The area of the sonotrode $\left(1.539 \mathrm{~cm}^{2}\right)$ gives an electrode power of 161.6 W. The sonotrode was inserted into a Hielscher stainless steel D14K temperature-controlled $15 \mathrm{~mL}$ flow vessel, sealed with two rubber O-rings. The system was used in continuous mode with a flow rate of $0.73 \mathrm{~mL} / \mathrm{s}$ to ensure a residence time of $20.5 \mathrm{~s}$. The resultant specific acoustic power was $10.8 \mathrm{~W} / \mathrm{mL}$. The treatment conditions applied, represent the maximum non-thermal pasteurization conditions possible with the equipment available. The treatment chamber was cooled during processing using a water jacket to ensure temperatures remained $<40{ }^{\circ} \mathrm{C}$. Preliminary results of batch experiments revealed power ultrasound at $\mathrm{T} \leq 10^{\circ} \mathrm{C}$ led to $1.9 \mathrm{log}$ reduction of $B$. bruxellensis (WLP 650 strain) in red wine (12.9\% alc. $v / v)$ after $30 \mathrm{~min}$ processing time.

\subsection{Quality Analysis of Wines}

2.6.1. Antioxidant Activity

Antioxidant activity was measured using a DPPH assay [29]. A $45 \mathrm{mg} / \mathrm{L}$ solution of DPPH (2,2-diphenylpicrylhydrazyl) in methanol was prepared for each analysis. All wine samples were diluted by a factor of 10 using a mixture of $12 \%$ ethanol in water before analysis. The standard used was an $80 \mathrm{mg} / \mathrm{L}$ solution of a vitamin E analogue, Trolox (6-hydroxy-2,5,7,8-tetramethylchroman-2-carboxylic acid). The method involved placing $200 \mu \mathrm{L}$ of diluted wine in a cell and adding $3 \mathrm{~mL}$ of the DPPH solution. A blank $(200 \mu \mathrm{L}$

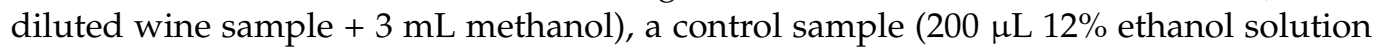
$+3 \mathrm{~mL}$ DPPH solution) and a Trolox standard $(200 \mu \mathrm{L}$ Trolox solution $+3 \mathrm{~mL} \mathrm{DPPH}$ solution) were also prepared at the same time. The absorbance at $517 \mathrm{~nm}$ of the control and blank samples were measured on a spectrophotometer (Perkin-Elmer Lambda 35 UV/Vis) after vigorous mixing. After $15 \mathrm{~min}$ of incubation at room temperature, the wine samples and Trolox standard were measured under the same conditions. All measurements were performed in duplicate. The results, expressed in millimoles Trolox equivalent per litre (mmol TE/L), were calculated as follows:

$$
\begin{gathered}
\text { Antioxidant activity }\left(\frac{\mathrm{mmol} \mathrm{TE}}{\mathrm{L}}\right)=0.32 \times D F_{w} \times \frac{A_{\text {control }(t=0)}-A_{\text {wine }}}{A_{\text {control }(t=0)}-A_{\text {Trolox }}} \\
A_{\text {wine }}=A_{\text {wine }(t=15)}-A_{\text {blank }(t=0)} \\
A_{\text {Trolox }}=A_{\text {Trolox }(t=15)}-A_{\text {blank }(t=0)}
\end{gathered}
$$

where $A$ is absorbance at $517 \mathrm{~nm}, t$ is incubation time and the $D F_{w}$ is the wine dilution factor of 10 .

\subsubsection{Total Phenolic Content}

To measure the total phenolic content of the wines, Folin-Ciocalteu assays were performed according to a method used previously [30]. The samples were incubated with Folin-Ciocalteu reagent and sodium carbonate before the phenolic concentration was quantified by spectral absorbance at $765 \mathrm{~nm}$ (Perkin-Elmer Lambda $35 \mathrm{UV} / \mathrm{Vis}$ ). Red wine samples were diluted by a factor of 10 before analysis. Using a calibration curve, total phenolic contents were expressed as gallic acid equivalents per litre of wine (GAE mg/L wine). All phenolic analyses were performed in duplicate. 


\subsubsection{Colour Density and $\mathrm{pH}$}

The colour density of the wine samples was determined by measuring the absorbance at 420, 520 and $620 \mathrm{~nm}$ using a Perkin-Elmer Lambda $35 \mathrm{UV} /$ Vis instrument. As proposed by [31], colour density was calculated as follows:

$$
\text { Colour density }=A_{420 \mathrm{~nm}}+A_{520 \mathrm{~nm}}+A_{620 \mathrm{~nm}}
$$

where $A$ is absorbance. The measurements were performed in a $1 \mathrm{~cm}$ cell using distilled water as a reference. All measurements were performed in duplicate.

The $\mathrm{pH}$ of the wine samples was measured using a HI2020 Multi-parameter $\mathrm{pH}$ Meter (Hanna Instruments, Smithfield, VA, USA).

\subsection{Data Analysis}

The quality parameter results of the treated wines using the different technologies and untreated wines were compared using statistical analysis. One-way analysis of variance (ANOVA) followed by Tukey tests, with a confidence level of $95 \%(p<0.05)$, were conducted using IBM SPSS Statistics (Version 23, New York, NY, USA).

\section{Results and Discussion}

\subsection{Quality Properties of Five Different Table Wines}

The antioxidant activity, total phenolic content, colour density and $\mathrm{pH}$ of the five untreated table wines are included in Table 2. As expected, antioxidant activity and total phenolic content were much higher in Syrah $(9.3 \pm 0.2 \mathrm{mmol} \mathrm{TE} / \mathrm{L}$ and $2540 \pm 140 \mathrm{mg} / \mathrm{L}$ GAE, respectively) and Pinot Noir (10.4 $\pm 0.1 \mathrm{mmol} \mathrm{TE} / \mathrm{L}$ and $2410 \pm 550 \mathrm{mg} / \mathrm{L} \mathrm{GAE}$, respectively) red wines compared to the Rosé $(2.8 \pm 0.2 \mathrm{mmol} \mathrm{TE} / \mathrm{L}$ and $440 \pm 40 \mathrm{mg} / \mathrm{L}$ GAE, respectively) and the two white wines Sauvignon Blanc $(2.5 \pm 0.1 \mathrm{mmol} \mathrm{TE} / \mathrm{L}$ and $290 \pm 10 \mathrm{mg} / \mathrm{L}$ GAE, respectively) and Pinot Gris $(4.5 \pm 0.3 \mathrm{mmol} \mathrm{TE} / \mathrm{L}$ and $510 \pm 10 \mathrm{mg} / \mathrm{L}$ GAE, respectively) wines. Similarly, the antioxidant activity and total phenolic content of red wines were 7.5 to $15.9 \mathrm{mmol} \mathrm{TE} / \mathrm{L}$ and 2600 to $4847 \mathrm{mg} / \mathrm{L}$ GAE, respectively [32]. The average antioxidant activity and total phenolic content of 21 red wines (including Cabernet Sauvignon wines) and eight white wines (including a Chardonnay) were lower at $5.52 \mathrm{mmol} \mathrm{TE} / \mathrm{L}$ an $1545 \mathrm{mg} / \mathrm{L}$ GAE, respectively for the red wines and $0.71 \mathrm{mmol} \mathrm{TE} / \mathrm{L}$ and $108 \mathrm{mg} / \mathrm{L} \mathrm{GAE}$, respectively for the white wines [33]. The colour density of the Syrah, Pinot Noir, Rosé, Sauvignon Blanc and Pinot Gris were $7.80 \pm 0.09,4.68 \pm 0.00,0.34 \pm 0.02$, $0.08 \pm 0.00$ and $0.26 \pm 0.00$, respectively. The original $\mathrm{pH}$ of all the untreated wines ranged between $3.28 \pm 0.01$ and $3.64 \pm 0.04$.

Table 2. Effect of HPP, PEF and US processing on quality parameters of five table wines processed by HPP, PEF and US *.

\begin{tabular}{|c|c|c|c|c|c|}
\hline Wines & Treatment & $\begin{array}{l}\text { Antioxidant Activity } \\
(\mathrm{mmol} T E / \mathrm{L}) \pm \mathrm{SD}\end{array}$ & $\begin{array}{l}\text { Total Phenolic Content } \\
\text { (mg/L GAE) } \pm \text { SD }\end{array}$ & Colour Density \pm SD & $\mathrm{pH} \pm \mathrm{SD}$ \\
\hline \multirow{4}{*}{ Syrah } & Untreated & $9.3 \pm 0.2^{c}$ & $2540 \pm 140^{\mathrm{a}, \mathrm{b}}$ & $7.80 \pm 0.09^{\mathrm{a}}$ & $3.64 \pm 0.04^{\mathrm{a}, \mathrm{b}}$ \\
\hline & HPP & $7.9 \pm 0.4^{\mathrm{c}}$ & $2930 \pm 270^{b}$ & $8.14 \pm 0.01^{b}$ & $3.80 \pm 0.05^{b}$ \\
\hline & PEF & $0.4 \pm 0.1^{\mathrm{a}}$ & $1700 \pm 100^{\mathrm{a}}$ & $8.71 \pm 0.02^{c}$ & $3.61 \pm 0.02^{\mathrm{a}}$ \\
\hline & US & $4.8 \pm 0.2^{b}$ & $1930 \pm 190^{\mathrm{a}, \mathrm{b}}$ & $8.40 \pm 0.01^{\mathrm{b}}$ & $3.60 \pm 0.02^{\mathrm{a}}$ \\
\hline \multirow{4}{*}{ Pinot Noir } & Untreated & $10.4 \pm 0.1^{\mathrm{f}}$ & $2410 \pm 550^{c}$ & $4.68 \pm 0.00^{\mathrm{d}}$ & $3.53 \pm 0.03^{c}$ \\
\hline & HPP & $8.0 \pm 0.2^{\mathrm{e}}$ & $2670 \pm 120^{c}$ & $4.89 \pm 0.06^{\mathrm{d}}$ & $3.54 \pm 0.03^{c}$ \\
\hline & PEF & $11.0 \pm 0.2^{\mathrm{f}}$ & $1600 \pm 90^{c}$ & $5.14 \pm 0.05^{\mathrm{e}}$ & $3.49 \pm 0.03^{c}$ \\
\hline & US & $4.8 \pm 0.1^{\mathrm{d}}$ & $1550 \pm 60^{c}$ & $4.88 \pm 0.00^{\mathrm{d}}$ & $3.55 \pm 0.01^{\mathrm{c}}$ \\
\hline \multirow{4}{*}{ Rosé } & Untreated & $2.8 \pm 0.2 \mathrm{~g}$ & $440 \pm 40^{\mathrm{d}}$ & $0.34 \pm 0.02^{\mathrm{f}}$ & $3.42 \pm 0.03^{d}$ \\
\hline & HPP & $2.4 \pm 0.2 \mathrm{~g}$ & $320 \pm 40^{\mathrm{d}, \mathrm{e}}$ & $0.38 \pm 0.00^{\mathrm{f}}$ & $3.45 \pm 0.04^{\mathrm{d}}$ \\
\hline & PEF & $2.2 \pm 0.1^{g}$ & $310 \pm 20^{\mathrm{d}, \mathrm{e}}$ & $0.38 \pm 0.08^{f}$ & $3.45 \pm 0.01^{\mathrm{d}}$ \\
\hline & US & $4.1 \pm 0.2^{\mathrm{h}}$ & $210 \pm 20^{\mathrm{e}}$ & $0.41 \pm 0.01^{\mathrm{f}}$ & $3.51 \pm 0.04^{\mathrm{d}}$ \\
\hline
\end{tabular}


Table 2. Cont.

\begin{tabular}{|c|c|c|c|c|c|}
\hline Wines & Treatment & $\begin{array}{l}\text { Antioxidant Activity } \\
(\mathrm{mmol} T E / \mathrm{L}) \pm \mathrm{SD}\end{array}$ & $\begin{array}{l}\text { Total Phenolic Content } \\
\quad(\mathrm{mg} / \mathrm{L} \text { GAE) } \pm \text { SD }\end{array}$ & Colour Density \pm SD & $\mathbf{p H} \pm \mathbf{S D}$ \\
\hline \multirow{4}{*}{$\begin{array}{l}\text { Sauvignon } \\
\text { Blanc }\end{array}$} & Untreated & $2.5 \pm 0.1^{\mathrm{i}}$ & $290 \pm 10^{g}$ & $0.08 \pm 0.00 \mathrm{~g}$ & $3.28 \pm 0.01^{\mathrm{e}, \mathrm{f}}$ \\
\hline & НРP & $2.2 \pm 0.4^{\mathrm{i}}$ & $270 \pm 10^{g}$ & $0.10 \pm 0.00 \mathrm{~g}$ & $3.34 \pm 0.02^{f}$ \\
\hline & PEF & $1.9 \pm 0.1^{\mathrm{i}}$ & $260 \pm 20 \mathrm{~g}$ & $0.20 \pm 0.01^{\mathrm{i}}$ & $3.21 \pm 0.01^{\mathrm{e}}$ \\
\hline & US & nd & $100 \pm 10^{\mathrm{f}}$ & $0.15 \pm 0.00^{\mathrm{h}}$ & $3.25 \pm 0.03^{\mathrm{e}}$ \\
\hline \multirow{4}{*}{ Pinot Gris } & Untreated & $4.5 \pm 0.3^{j}$ & $510 \pm 10^{\mathrm{i}}$ & $0.26 \pm 0.00^{\mathrm{k}}$ & $3.57 \pm 0.08 \mathrm{~g}$ \\
\hline & HРP & $4.7 \pm 0.2^{\mathrm{j}}$ & $590 \pm 100^{\mathrm{i}}$ & $0.24 \pm 0.00^{\mathrm{j}}$ & $3.57 \pm 0.03 \mathrm{~g}$ \\
\hline & PEF & $3.5 \pm 0.2^{\mathrm{j}}$ & $510 \pm 30^{\mathrm{i}}$ & $0.37 \pm 0.00^{1}$ & $3.55 \pm 0.02 \mathrm{~g}$ \\
\hline & US & nd & $100 \pm 10^{\mathrm{h}}$ & $0.27 \pm 0.00^{\mathrm{k}}$ & $3.49 \pm 0.02 \mathrm{~g}$ \\
\hline
\end{tabular}

* For each wine and quality parameter, different letters indicate difference in treatment's average value Tukey tests $(p<0.05)$; high pressure processing (HPP), pulsed electric fields (PEF), ultrasound (US); nd-antioxidant activity not detected.

\subsection{Effect of HPP, PEF and US Processing on the Quality of Five Wines Directly after Processing}

Table 2 and Figures 1-4 (values labelled 'directly after') show the antioxidant activity, total phenolic content, colour density and $\mathrm{pH}$ of the five treated wines directly after processing and respective untreated wines. For each wine, the antioxidant activity, total phenolic content, colour density and $\mathrm{pH}$ of HPP, PEF and US treated wines were compared to the untreated wines.

\subsubsection{HPP}

HPP treatment of $600 \mathrm{MPa}$ for $5 \mathrm{~min}$ was found to have no statistically significant effect on the total phenolic content or $\mathrm{pH}$ of all five wines. The antioxidant activity of all wines resulted in similar values to the untreated wines after HPP except for a decrease in the Pinot Noir from $10.4 \pm 0.1$ to $8.0 \pm 0.2 \mathrm{mmol}$ TE/L. HPP had no effect on the colour density of the Sauvignon Blanc, Rosé or Pinot Noir. However, the colour density of the Pinot Gris decreased slightly from $0.26 \pm 0.00$ to $0.24 \pm 0.00$ and increased for the Syrah from $7.80 \pm 0.09$ to $8.14 \pm 0.01$. However, a longer HPP treatment of $15 \mathrm{~min}$ of a Syrah red wine (650 MPa) led to a decrease in total phenolic content [34]. HPP of red wine (500 MPa, $5 \mathrm{~min}$ ) resulted in no significant change in the colour of the wine and slight increases in the total phenolic content and antioxidant activity of the wine directly after processing [26]. Repeating this study with white wine resulted in no change in the colour, total phenolic content or antioxidant activity of the wine directly after processing compared to the untreated wine [27]. HPP had no significant effect on the colour of a sparkling white wine subjected to $600 \mathrm{MPa}$ for $2 \mathrm{~min}$ [35]. In general the results presented, in accordance with previous research, suggest that HPP has little to no effect on wine quality parameters investigated directly after processing.

\subsubsection{PEF}

As found with the HPP treated wines, PEF had no effect on the total phenolic content or $\mathrm{pH}$ of all wines compared to the untreated wines directly after processing (Table 2). No change in the antioxidant activity of PEF treated wines was found, except for a decrease observed in the Syrah from $9.3 \pm 0.2$ to $0.4 \pm 0.1 \mathrm{mmol}$ TE/L. PEF increased the colour density of the red wines (Syrah $7.80 \pm 0.09$ to $8.71 \pm 0.02$ and Pinot Noir $4.68 \pm 0.00$ to $5.14 \pm 0.05$ ) as well as the white wines (Sauvignon Blanc $0.08 \pm 0.00$ to $0.20 \pm 0.01$ and Pinot Gris $0.26 \pm 0.00$ to $0.37 \pm 0.00$ ). Similar to the results presented, it was found that the total phenolic content and antioxidant activity of PEF treated $\left(31 \mathrm{kV} / \mathrm{cm}, 30^{\circ} \mathrm{C}, 3 \mu \mathrm{s}\right.$ square bipolar pulses, $40 \mathrm{~mL} / \mathrm{min}$ ) red wine were unchanged directly after processing [21]. Additionally, after eight days of storage, PEF treated red wine $(20 \mathrm{kV} / \mathrm{cm}, 0.5 \mathrm{~Hz}, 10 \mu \mathrm{s}$ exponential decay pulses) resulted in a $1 \%$ increase in $\mathrm{pH}, 2 \%$ decrease in colour intensity and $5 \%$ increase in total phenolic content [25]. 


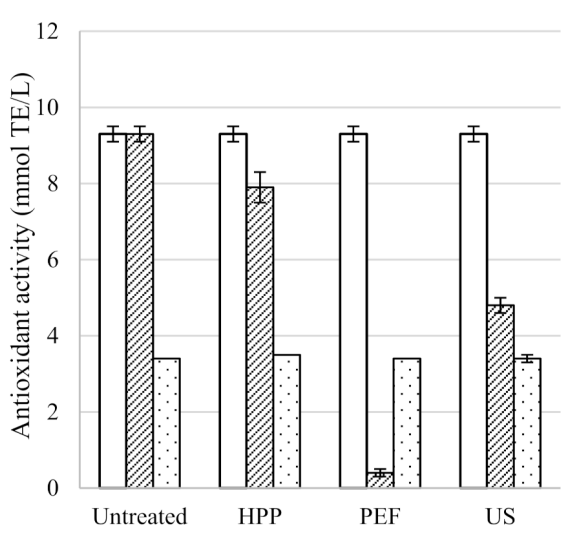

(a)

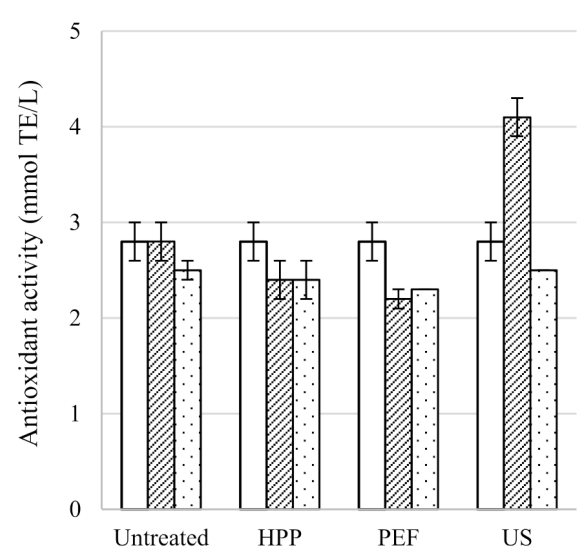

(c)

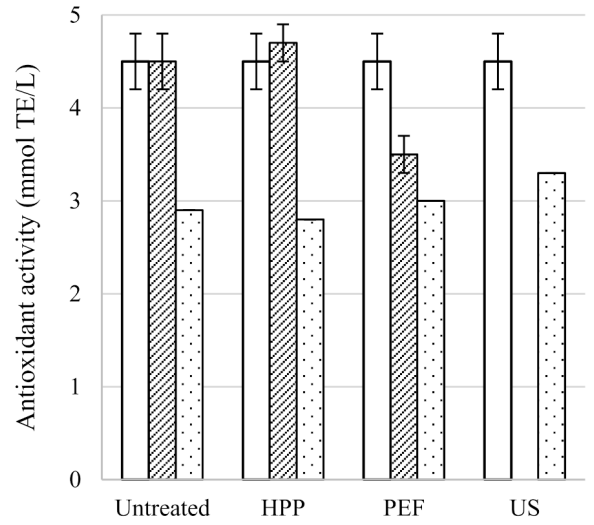

(e)

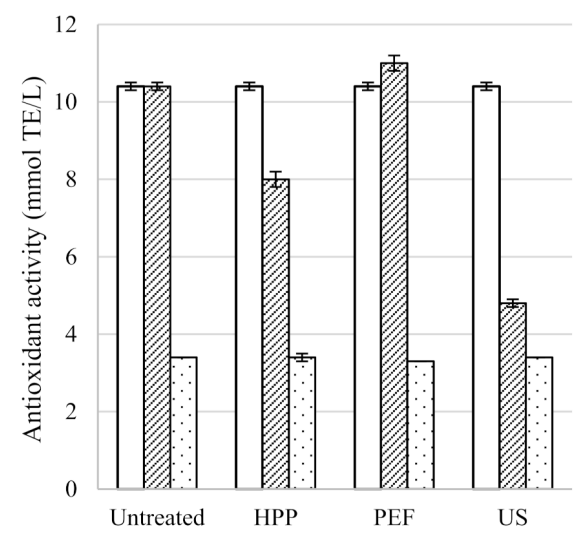

(b)

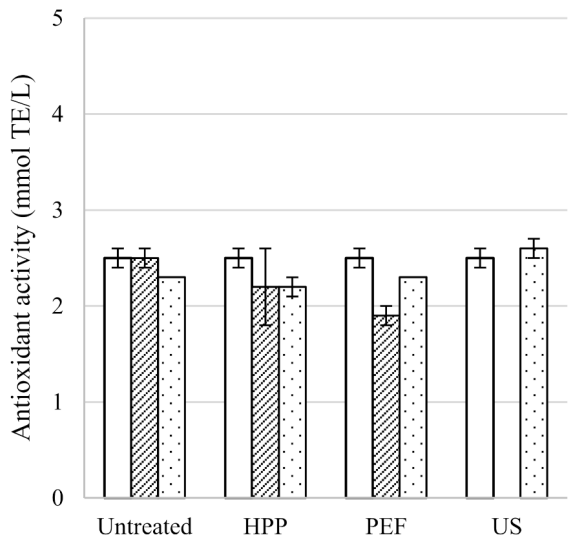

(d)

\section{$\square$ Before \\ $\square$ Directly after \\ $\square 2$ Months}

Figure 1. Antioxidant activity of untreated, high pressure processing (HPP), pulsed electric fields (PEF) and ultrasound (US) treated wines before, directly after processing and after two months storage at $15{ }^{\circ} \mathrm{C}$; (a) Syrah, (b) Pinot Noir, (c) Rosé, (d) Sauvignon Blanc and (e) Pinot Gris. 


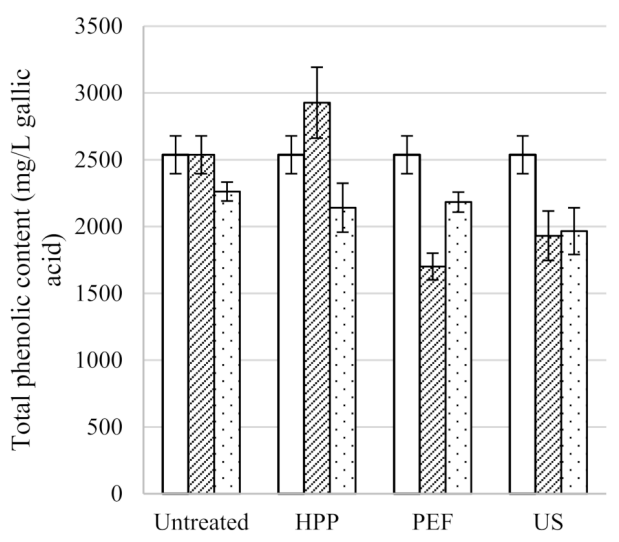

(a)

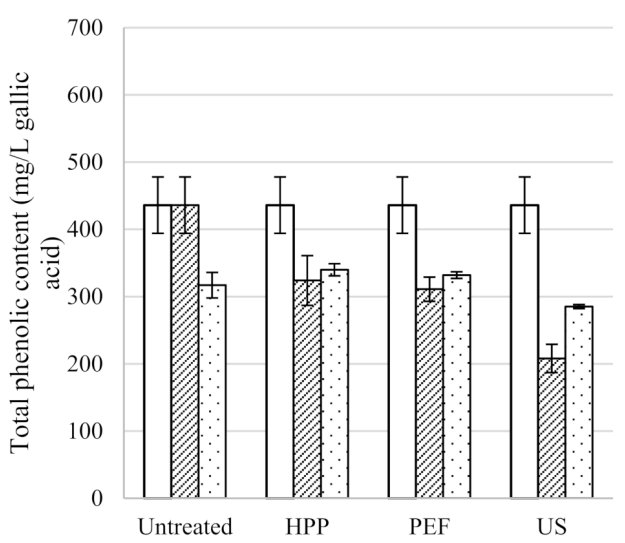

(c)

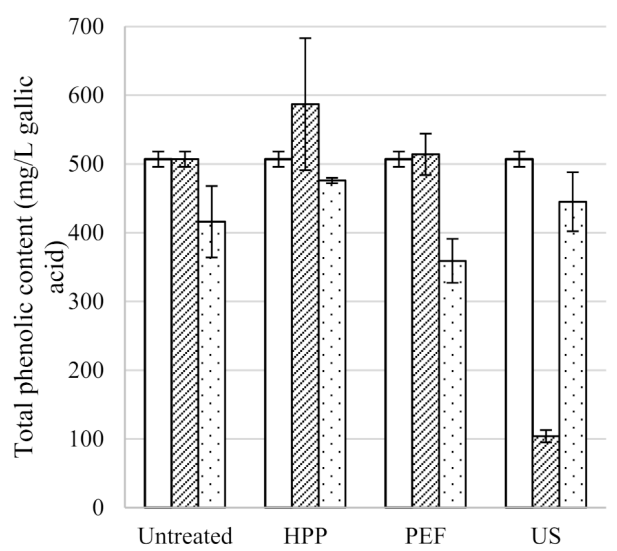

(e)

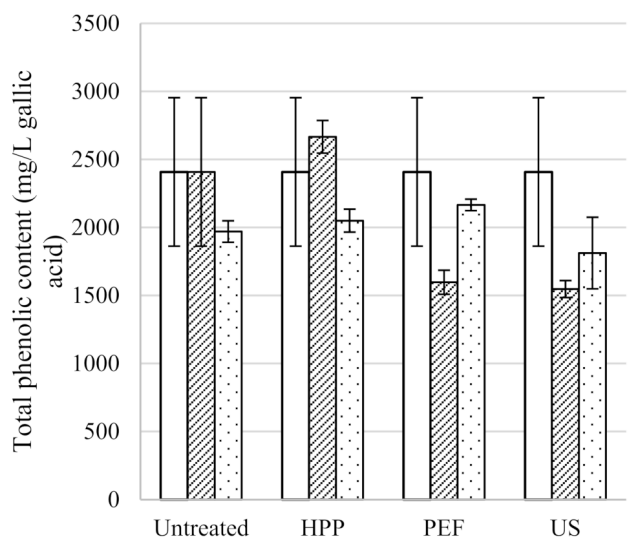

(b)

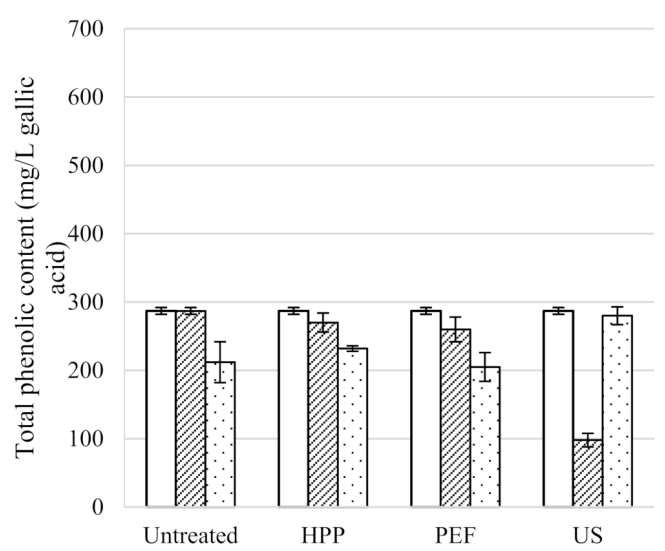

(d)
口Before

$\square$ Directly after

$\square 2$ Months

Figure 2. Total phenolic content of untreated, HPP, PEF and US treated wines before, directly after processing and after two months storage at $15{ }^{\circ} \mathrm{C}$; (a) Syrah, (b) Pinot Noir, (c) Rosé, (d) Sauvignon Blanc and (e) Pinot Gris. 


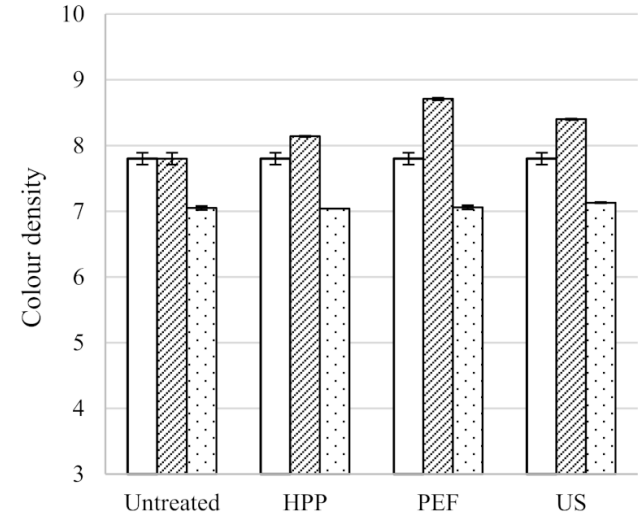

(a)

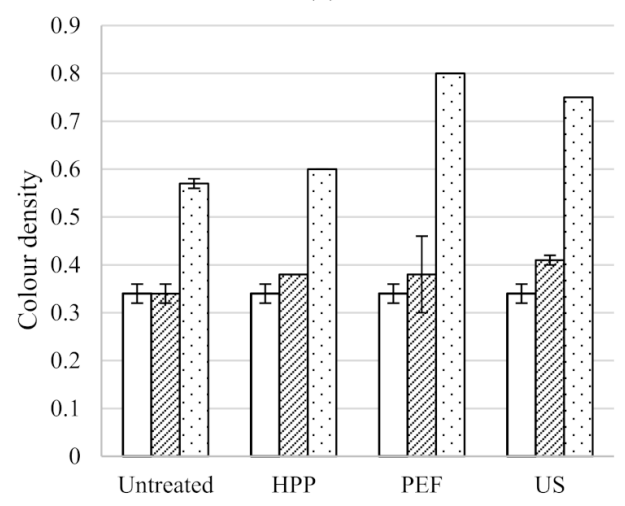

(c)

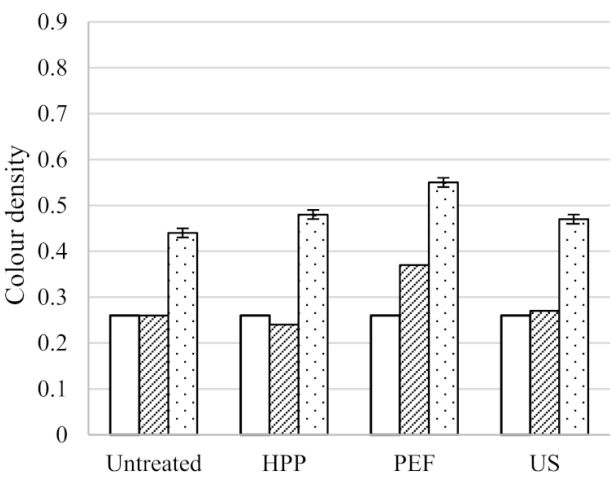

(e)

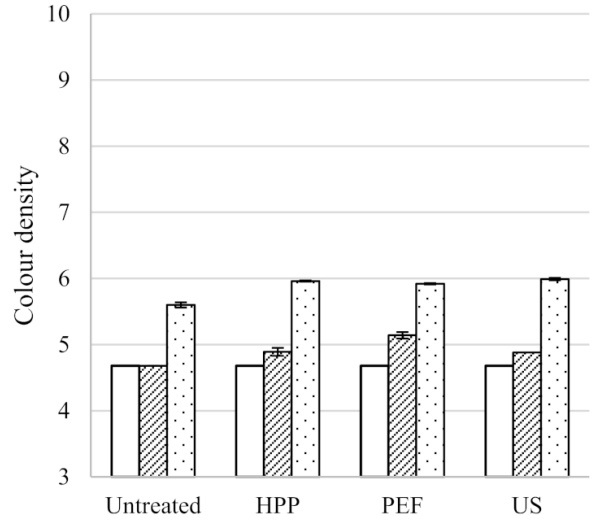

(b)

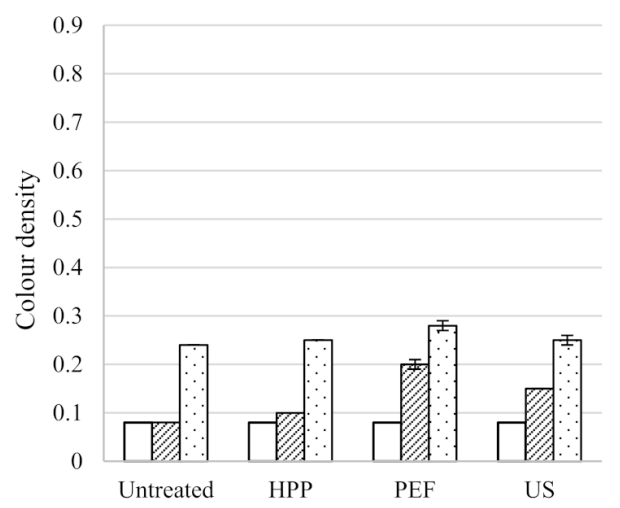

(d) $\square$ Before

$\square$ Directly after

๑2 Months

Figure 3. Colour density of untreated, HPP, PEF and US treated wines before, directly after processing and after two months storage at $15^{\circ} \mathrm{C}$; (a) Syrah, (b) Pinot Noir, (c) Rosé, (d) Sauvignon Blanc and (e) Pinot Gris. 


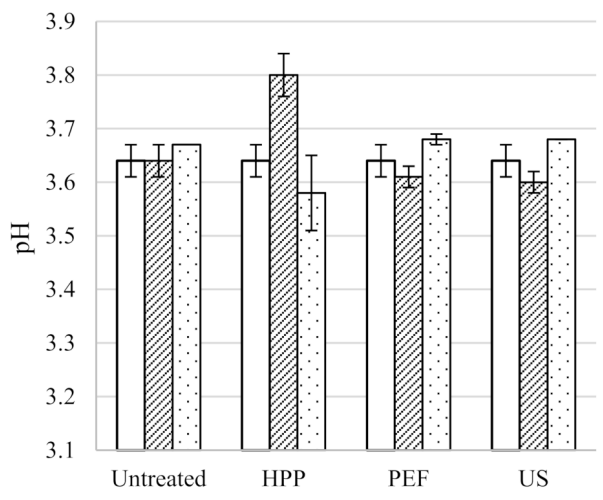

(a)

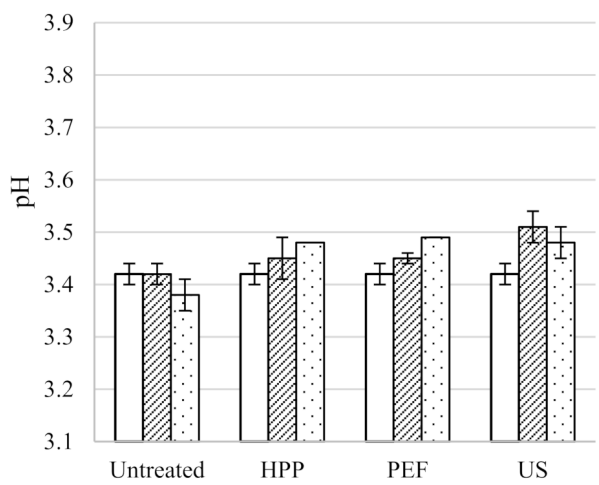

(c)

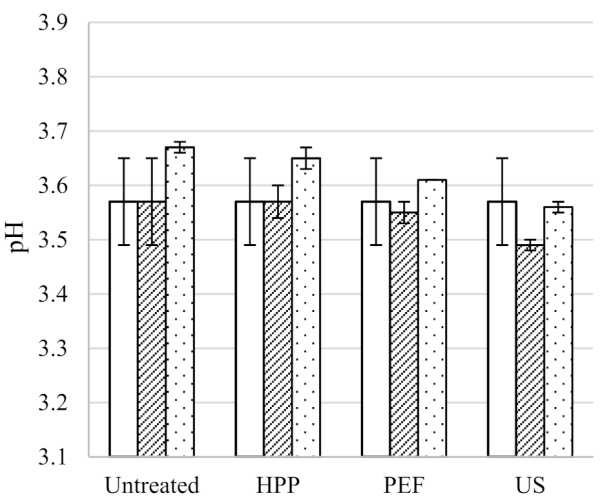

(e)

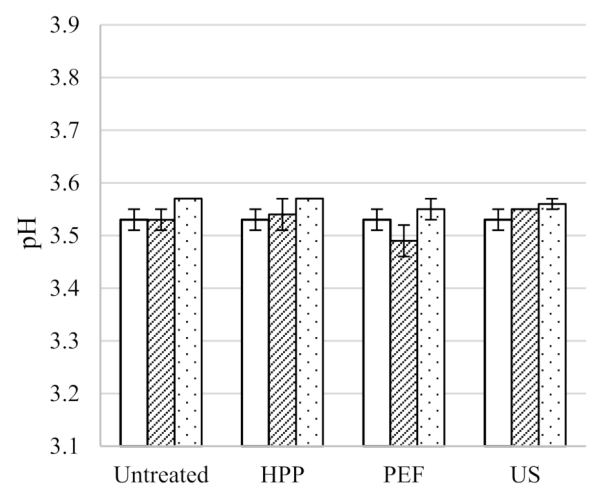

(b)

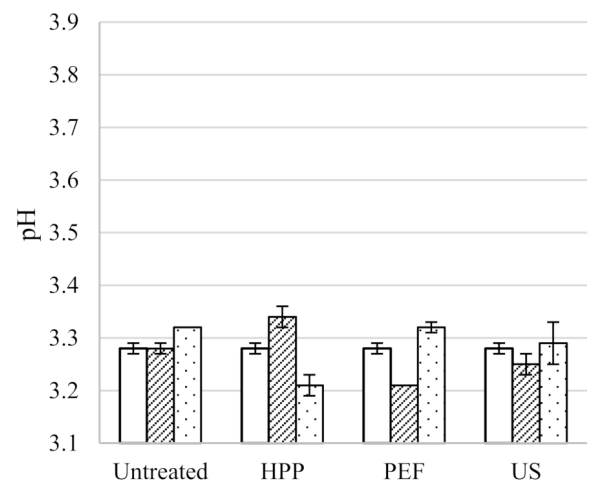

(d) $\square$ Before
$\square$ Directly after
$\square 2$ Months

Figure 4. $\mathrm{pH}$ of untreated, HPP, PEF and US treated wines before, directly after processing and after two months storage at $15^{\circ} \mathrm{C}$; (a) Syrah, (b) Pinot Noir, (c) Rosé, (d) Sauvignon Blanc and (e) Pinot Gris.

\subsubsection{US}

US also had no effect on the $\mathrm{pH}$ of all treated wines directly after processing. As with HPP and PEF, the total phenolic content of the Syrah and Pinot Noir red wines presented similar values to the untreated wines. However, unlike the other technologies, US decreased the total phenolic content of the Sauvignon Blanc (290 \pm 10 to $100 \pm 10 \mathrm{mg} / \mathrm{L} \mathrm{GAE})$, Pinot Gris (510 \pm 10 to $100 \pm 10 \mathrm{mg} / \mathrm{L} \mathrm{GAE})$. The US treatment of Rosé wine reduced the TPC from $440 \pm 40 \mathrm{mg} / \mathrm{L}$ GAE (untreated) to $210 \pm 20 \mathrm{mg} / \mathrm{L}$ GAE (US treated), although TPC of US, HPP and PEF wines was not statistically different. The antioxidant activity of the Rosé increased from $2.8 \pm 0.2$ to $4.1 \pm 0.2 \mathrm{mmol}$ TE/L directly after ultrasound treatment. This result is unusual since previous studies have found that there is a positive relationship between total phenolic content and antioxidant activity [36]. It is also known 
that US can produce hydroxyl radicals during sonication with the aromatic ring of phenolic compounds, which in turn increases total phenolic content [37]. The antioxidant activity decreased for both Syrah $(9.3 \pm 0.2$ to $4.8 \pm 0.2 \mathrm{mmol} \mathrm{TE} / \mathrm{L})$ and Pinot Noir $(10.4 \pm 0.1$ to $4.8 \pm 0.1 \mathrm{mmol} \mathrm{TE} / \mathrm{L})$. The colour density of most wines remained stable directly after ultrasound treatment except for a slight increase for the Sauvignon Blanc $(0.08 \pm 0.00$ to $0.15 \pm 0.00)$ and Syrah $(7.80 \pm 0.09$ to $8.40 \pm 0.01)$. Previous research concluded that US has the potential to speed up the ageing of wine [22,38]. General trends observed in the wines were that US decreased antioxidant activity, total phenolic content and $\mathrm{pH}$ directly after processing, while increasing colour density.

\subsubsection{Comparison of the Three Technologies' Effect on Quality Parameters}

Comparing the three non-thermal technologies directly after processing, HPP and PEF had no effect on the total phenolic content of the wines treated. However, US significantly decreased the total phenolic content of the white and Rosé wines. The results of the Syrah wine shows that HPP had no effect on antioxidant activity while US and PEF caused a decrease $(9.3 \pm 0.2$ in untreated wine to $4.8 \pm 0.2$ and $0.4 \pm 0.1 \mathrm{mmol} \mathrm{TE} / \mathrm{L}$, respectively). The same trend resulted from the colour density data of the Syrah wine, with HPP and US causing the smallest increase in colour density and PEF the most. Therefore, HPP had the smallest effect on the quality factors assessed in the wines. General wine quality trends (not all statistically significant) suggest that HPP, PEF and US have potential for preserving wine and possibly the acceleration of wine ageing.

\subsection{Effect of Two Months Storage Quality Parameters of Five Different Table Wines Untreated and HPP, PEF and US Treated}

The wine microbial spoilage can be indirectly monitored by the $\mathrm{pH}$ assessed during 2 months storage, as the wine $\mathrm{pH}$ decreases with microbial growth [37]. The results showed that generally the $\mathrm{pH}$ of the five wines untreated and treated with different technologies is not significantly different before storage and after 2 months storage (Figure 4).

\subsubsection{Trends in Quality Parameters with Storage}

During prolonged wine storage, antioxidant activity and total phenolic content usually decrease while colour density increases. As a result of processing and storage, it is generally desired that antioxidant activity and total phenolic content increase or remain unchanged. As colour density increases, wine colour becomes darker. Evidence has shown that increasing colour density is linked to higher quality ratings in red wine [39]. However, consumer preference dictates whether an increasing or decreasing wine colour density with processing and storage is beneficial to the wine quality.

Figure 1 shows the trends in the antioxidant activity of the five non-thermal treated and corresponding untreated wines after two months storage. Results show that the antioxidant activity of the wines generally decreased with storage. A possible explanation for the decrease in antioxidant activity could be an increase in condensation reactions of the phenolic compounds in the wines [26,27]. It was established that the antioxidant activity of the untreated and HPP treated ( $500 \mathrm{MPa}, 5 \mathrm{~min}$ ) red wine (Touriga Nacional grape variety) increased during the first three months and then decreased during the rest of the storage, with the antioxidant activity of the treated wine being higher than the untreated wine throughout storage [26]. For the white wine (Encruzado grape variety), a slight increase in antioxidant activity during storage was observed.

The total phenolic content of the untreated, HPP and PEF treated white wines (Sauvignon Blanc and Pinot Gris) also decreased slightly during the two months storage period (Figure 2). Total phenolic content is an important wine quality parameter with significant technological implications regarding wine ageing. Since the phenolic compounds in the wines contribute to bitterness, astringency, mouthfeel and colour, this suggests that the sensory properties of the wines treated using HPP and PEF are also impacted $[19,31]$. The total phenolic content of the untreated red wine remained stable at $2250 \mathrm{mg} / \mathrm{L} \mathrm{GAE}$ during storage, while the HPP treated red wine decreased to $2050 \mathrm{mg} / \mathrm{L} \mathrm{GAE} \mathrm{[26].} \mathrm{The} \mathrm{same}$ 
trend was observed with the HPP treated white wine with the untreated total phenolic content remaining stable at $350 \mathrm{mg} / \mathrm{L} \mathrm{GAE}$ and the total phenolic content of the treated wine decreasing slightly to $320 \mathrm{mg} / \mathrm{L} \mathrm{GAE} \mathrm{[27].}$

Figure 3 shows the colour density of the five untreated and non-thermal treated wines stored after a period of two months. The colour density of the wines generally increased during storage, the Syrah wine being the exception, which resulted in a decrease in colour density during the two months storage. The colour of a red and white wine subjected to HPP (500 MPa, $5 \mathrm{~min}$ ) has been monitored during one year storage [26,27]. It was found that the CIE colour parameters of the untreated and HPP treated red and white wines increased during storage. The colour density of all untreated (except the Syrah) wines were generally lower than the treated wines after processing and storage. HPP, PEF and US have been known to activate and accelerate browning caused by the Maillard reaction and polyphenol oxidase [27]. This explains the increased colour density in HPP, PEF and US treated wines compared to the untreated wines.

Figure 4 shows that $\mathrm{pH}$ generally remained unchanged during storage, compared to the untreated wines.

\subsubsection{Comparison of Quality Parameters of Untreated and Treated Wine after 2 Month Storage}

The antioxidant activity, total phenolic content, colour density and $\mathrm{pH}$ after two months storage of untreated and HPP, PEF and US treated wines is shown in Table 3 and Figures 1-4. No significant difference was detected between the total phenolic content or $\mathrm{pH}$ of untreated, HPP, PEF and US treated wines at the end of 2 months storage (except for a slight decrease in the $\mathrm{pH}$ of the US treated Pinot Gris). Generally, after 2 months storage the antioxidant activity of untreated, HPP, PEF and US treated wines were similar, with the exception of US with a higher antioxidant activity of the Pinot Gris, and HPP with a lower antioxidant activity, compared to the untreated wine.

Table 3. Effect of two months storage at $15^{\circ} \mathrm{C}$ on quality parameters of five table wines untreated and processed by $\mathrm{HPP}$, PEF and US *.

\begin{tabular}{|c|c|c|c|c|c|}
\hline Wines & Treatment & $\begin{array}{l}\text { Antioxidant Activity } \\
(\mathrm{mmol} T \mathrm{TE} / \mathrm{L}) \pm \mathrm{SD}\end{array}$ & $\begin{array}{l}\text { Total Phenolic Content } \\
\quad(\mathrm{mg} / \mathrm{L} \mathrm{GAE}) \pm \mathrm{SD}\end{array}$ & Colour Density \pm SD & $\mathrm{pH} \pm \mathrm{SD}$ \\
\hline \multirow{4}{*}{ Syrah } & Untreated & $3.5 \pm 0.0^{\mathrm{a}}$ & $2260 \pm 70^{a}$ & $7.05 \pm 0.03^{a}$ & $3.67 \pm 0.01^{\mathrm{a}}$ \\
\hline & HPP & $3.5 \pm 0.0^{\mathrm{a}}$ & $2140 \pm 180^{a}$ & $7.04 \pm 0.00^{\mathrm{a}}$ & $3.58 \pm 0.07^{\mathrm{a}}$ \\
\hline & PEF & $3.4 \pm 0.0^{\mathrm{a}}$ & $2180 \pm 80^{a}$ & $7.06 \pm 0.03^{a}$ & $3.68 \pm 0.01^{\mathrm{a}}$ \\
\hline & US & $3.4 \pm 0.1^{\mathrm{a}}$ & $1970 \pm 180^{a}$ & $7.13 \pm 0.01^{\mathrm{a}}$ & $3.68 \pm 0.00^{\mathrm{a}}$ \\
\hline \multirow{4}{*}{ Pinot Noir } & Untreated & $3.4 \pm 0.0^{b}$ & $1970 \pm 80^{b}$ & $5.60 \pm 0.04^{b}$ & $3.57 \pm 0.00^{b}$ \\
\hline & HPP & $3.4 \pm 0.1^{b}$ & $2050 \pm 80^{b}$ & $5.96 \pm 0.01^{c}$ & $3.57 \pm 0.01^{b}$ \\
\hline & PEF & $3.3 \pm 0.0^{b}$ & $2170 \pm 40^{b}$ & $5.92 \pm 0.01^{c}$ & $3.55 \pm 0.02^{b}$ \\
\hline & US & $3.4 \pm 0.0^{b}$ & $1810 \pm 50^{b}$ & $5.99 \pm 0.02^{c}$ & $3.56 \pm 0.01^{b}$ \\
\hline \multirow{4}{*}{ Rosé } & Untreated & $2.5 \pm 0.1^{c}$ & $320 \pm 20^{c}$ & $0.57 \pm 0.01^{\mathrm{d}}$ & $3.38 \pm 0.03^{c}$ \\
\hline & HРP & $2.4 \pm 0.2^{\mathrm{c}}$ & $340 \pm 10^{c}$ & $0.60 \pm 0.00^{\mathrm{e}}$ & $3.48 \pm 0.00^{c}$ \\
\hline & PEF & $2.3 \pm 0.0^{\mathrm{c}}$ & $330 \pm 10^{c}$ & $0.80 \pm 0.00 \mathrm{~g}$ & $3.49 \pm 0.00^{\mathrm{c}}$ \\
\hline & US & $2.5 \pm 0.0^{\mathrm{c}}$ & $290 \pm 10^{c}$ & $0.75 \pm 0.00^{\mathrm{f}}$ & $3.48 \pm 0.04^{\mathrm{c}}$ \\
\hline \multirow{4}{*}{$\begin{array}{l}\text { Sauvignon } \\
\text { Blanc }\end{array}$} & Untreated & $2.3 \pm 0.0^{\mathrm{d}, \mathrm{e}}$ & $210 \pm 30^{d}$ & $0.24 \pm 0.00^{h}$ & $3.32 \pm 0.00^{d}$ \\
\hline & НРP & $2.2 \pm 0.1^{\mathrm{d}}$ & $230 \pm 10^{\mathrm{d}}$ & $0.25 \pm 0.00^{h}$ & $3.21 \pm 0.02^{d}$ \\
\hline & PEF & $2.3 \pm 0.0^{\mathrm{d}, \mathrm{e}}$ & $210 \pm 20^{d}$ & $0.28 \pm 0.01^{h}$ & $3.32 \pm 0.01^{\mathrm{d}}$ \\
\hline & US & $2.6 \pm 0.1^{\mathrm{e}}$ & $280 \pm 10^{d}$ & $0.26 \pm 0.01^{h}$ & $3.29 \pm 0.04^{\mathrm{d}}$ \\
\hline \multirow{4}{*}{ Pinot Gris } & Untreated & $2.9 \pm 0.0^{g}$ & $420 \pm 50^{\mathrm{e}}$ & $0.44 \pm 0.01^{\mathrm{i}}$ & $3.67 \pm 0.01^{\mathrm{f}}$ \\
\hline & НPP & $2.8 \pm 0.0^{f}$ & $480 \pm 10^{\mathrm{e}}$ & $0.48 \pm 0.01^{j}$ & $3.65 \pm 0.03^{f}$ \\
\hline & PEF & $3.0 \pm 0.0^{g}$ & $360 \pm 30^{\mathrm{e}}$ & $0.55 \pm 0.01^{\mathrm{k}}$ & $3.61 \pm 0.01 \mathrm{e}, \mathrm{f}$ \\
\hline & US & $3.3 \pm 0.0^{\mathrm{h}}$ & $450 \pm 40^{\mathrm{e}}$ & $0.47 \pm 0.01^{i, j}$ & $3.56 \pm 0.01^{\mathrm{e}}$ \\
\hline
\end{tabular}

* For each wine and quality parameter, different letters indicate difference in treatment's average value Tukey tests $(p<0.05)$; high pressure processing (HPP), pulsed electric fields (PEF), ultrasound (US). 
For Sauvignon Blanc and Syrah, the colour density of untreated and treated wine (HPP, PEF, US) was similar after 2 months storage. However, the following HPP wines presented higher colour density than the corresponding stored untreated wine after 2 months storage: Pinot Gris ( $0.48 \pm 0.01$ vs. $0.44 \pm 0.01)$, Rosé $(0.60 \pm 0.00$ vs. $0.57 \pm 0.01)$ and Pinot Noir $(5.96 \pm 0.01$ vs. $5.60 \pm 0.04)$. Previous authors found that HPP treated red wine (500 MPa, $5 \mathrm{~min}$ ) showed no significant difference in colour, total phenolic content or antioxidant activity compared to untreated wine after three months storage at $10-15^{\circ} \mathrm{C}$ [26]. The same experiments conducted with a white wine resulted in a decrease in the CIE colour parameters, a slight decrease in antioxidant activity and a slight increase in total phenolic content [27].

As with HPP, PEF colour density was higher than the untreated wine for the Pinot Gris $(0.55 \pm 0.01$ vs. $0.44 \pm 0.01)$, Rosé $(0.80 \pm 0.00$ vs. $0.57 \pm 0.01)$ and Pinot Noir $(5.92 \pm 0.01$ vs. $5.60 \pm 0.04)$. Furthermore, for the Rosé, Sauvignon Blanc and Pinot Gris, the colour density of PEF treated wines was the highest after storage, compared with untreated, HPP and US wines.

Regarding US treated wines, the colour density of the Sauvignon Blanc, Pinot Gris and Syrah US wines was similar to the stored untreated sample. On the contrary, Rosé ( $0.75 \pm 0.00$ vs. $0.57 \pm 0.01)$ and Pinot Noir (5.99 \pm 0.02 vs. $5.60 \pm 0.04)$ had higher values than the untreated wine. The antioxidant activity of the US treated Pinot Gris was higher $(3.3 \pm 0.0 \mathrm{mmol} \mathrm{TE} / \mathrm{L})$ compared to the untreated $(2.9 \pm 0.0 \mathrm{mmol} \mathrm{TE} / \mathrm{L})$, while the other wines were similar to the untreated stored wine sample.

\section{Conclusions}

HPP and PEF had no effect on the total phenolic content of the treated wines. Nonthermal processing had no effect on the antioxidant activity of HPP treated white and Rosé wines, US treated white wines and all PEF wines except the Syrah directly after processing. Comparing the antioxidant activity and total phenolic content results from the Syrah wine, HPP had the smallest effect on these wine quality parameters directly after processing followed by PEF and lastly US. HPP, PEF and US had no significant effect on the $\mathrm{pH}$ of all five wines treated directly after processing, and the $\mathrm{pH}$ of the untreated and treated wines generally remained unchanged during storage.

After two months storage, no significant effect on the total phenolic content of any of the five wines treated was observed as a result of non-thermal processing. Compared to the untreated wines, there was no difference in the antioxidant activity of all but one wine subjected to HPP, PEF or US after two months storage. Regarding Pinot Gris, HPP increased colour density less than PEF treatment. In the case of Rosé wines, HPP followed by US and PEF had the smallest effect on colour density after two months storage. As found directly after processing, HPP had the smallest overall effect on wine quality factors after two months storage. HPP is a promising preservation technology, as quality factors assessed remained stable during two months storage after a treatment which is able to cause $>6 \log$ reductions of Brettanomyces bruxellensis. The other technologies also have potential, maintaining the quality factors investigated constant during two months storage. Although microbes might be present after processing, the alcohol content of the wines $(12.5-13.5 \% v / v)$ did not allow them to grow during storage, so wines kept their properties. In general, the US process caused a reduction in the TPC and antioxidant activity of the wines, while PEF and HPP did not affect these quality factors directly after processing. However, after 2 months storage no differences were registered between the processed (HPP, PEF, US) and untreated samples of wine.

In future studies the effect of the novel technologies on other parameters important to assess the wine quality should be investigated, namely fixed and volatile acidity, total sugars, reducing sugars, residual sugar, alcoholic strength $(\% v / v)$ and sulfur dioxide content (if added to the wine). Analysis of tannins and anthocyanins content of the wines could also be determined through HPLC profiles. To compare the viability of HPP, PEF and US with the traditional $\mathrm{SO}_{2}$ treatment, it is important that future experiments are carried out 
with $\mathrm{SO}_{2}$ preservative free wines treated with specific processing conditions of non-thermal technologies which deliver the same lethality (intensity) in the target microorganism of concern (e.g., Brett). Additionally, longer wine storage experiments up to 6-12 months should be carried out to mimic the real wine conservation time.

Author Contributions: Conceptualization and methodology, F.V.M.S.; experimental work, L.H.; data analysis, S.v.W., L.H., F.V.M.S.; writing, review and editing, S.v.W., F.V.M.S.; supervision and project administration, F.V.M.S. All authors have read and agreed to the published version of the manuscript.

Funding: University of Auckland Doctoral and Morton Coutts Scholarships are greatly valued. Project n. 3708802 of "Non-thermal pasteurization of beer and other alcoholic beverages" also funded by Morton Coutts, Dominion Breweries is acknowledged.

Institutional Review Board Statement: Not applicable.

Informed Consent Statement: Not applicable.

Acknowledgments: The support from the University of Auckland, especially from the staff of the Chemical and Materials Engineering Department is appreciated. The support of Randy Weaver, director of the Wine Science Program at the University of Auckland is also acknowledged.

Conflicts of Interest: The authors declare no conflict of interest.

\section{References}

1. Jackson, R.S. (Ed.) Introduction. In Wine Science, 4th ed.; Academic Press: San Diego, CA, USA, 2014; pp. 1-19.

2. Miele USA. Operating and Installation Instructions, User Manual. 2017. Available online: http://us.mieleusa.com/MieleMedia/ docs/products/OpIn/manuals_pdf/Cooling/Wine_Storage/KWT1601SF_us.pdf (accessed on 10 October 2021).

3. Jackson, R.S. Shelf life of wine. In Food and Beverage Stability and Shelf Life; Kilcast, D., Subramaniam, P., Eds.; Woodhead Publishing: Sawston, UK, 2011; pp. 540-570.

4. Han, G.; Ugliano, M.; Currie, B.; Vidal, S.; Diéval, J.; Waterhouse, A.L. Influence of closure, phenolic levels and microoxygenation on Cabernet Sauvignon wine composition after 5 years' bottle storage. J. Sci. Food Agric. 2015, 95, 36-43. [CrossRef]

5. Marquez, A.; Serratosa, M.P.; Merida, J. Influence of bottle storage time on colour, phenolic composition and sensory properties of sweet red wines. Food Chem. 2014, 146, 507-514. [CrossRef] [PubMed]

6. Arapitsas, P.; Speri, G.; Angeli, A.; Perenzoni, D.; Mattivi, F. The influence of storage on the "chemical age" of red wines. Metabolomics 2014, 10, 816-832. [CrossRef]

7. van Wyk, S.; Farid, M.; Silva, F.V.M. $\mathrm{SO}_{2}$, high pressure processing and pulsed electric field treatments of red wine: Effect on sensory, Brettanomyces inactivation and other quality parameters during one year storage. Innov. Food Sci. Emerg. Technol. 2018, 48, 204-211. [CrossRef]

8. Evelyn Kim, H.J.; Silva, F.V.M. Modeling the inactivation of Neosartorya fischeri ascospores in apple juice by high pressure, power ultrasound and thermal processing. Food Control 2016, 59, 530-537. [CrossRef]

9. Milani, E.A.; Silva, F.V.M. Nonthermal pasteurization of beer by high pressure processing: Modelling the inactivation of Saccharomyces cerevisiae ascospores in different alcohol beers. High Press. Res. 2016, 36, 595-609. [CrossRef]

10. Mok, C.; Song, K.; Park, Y.; Lim, S.; Ruan, R.; Chen, P. High Hydrostatic Pressure Pasteurization of Red Wine. J. Food Sci. 2006, 71, 265-269. [CrossRef]

11. Silva, F.V.M.; Tan, E.K.; Farid, M. Bacterial spore inactivation at $45-65^{\circ} \mathrm{C}$ using High Pressure Processing: Study of Alicyclobacillus acidoterrestris in orange juice. Food Microbiol. 2012, 32, 206-211. [CrossRef]

12. van Wyk, S.; Silva, F.V.M. High pressure inactivation of Brettanomyces bruxellensis in red wine. Food Microbiol. 2017, 63, 199-204. [CrossRef]

13. van Wyk, S.; Silva, F.V.M. High pressure processing inactivation of Brettanomyces bruxellensis in seven different table wines. Food Control 2017, 81, 1-8. [CrossRef]

14. Buzrul, S. High hydrostatic pressure treatment of beer and wine: A review. Innov. Food Sci. Emerg. Technol. 2012, 13, 1-12. [CrossRef]

15. Mújica-Paz, H.; Valdez-Fragoso, A.; Samson, C.T.; Welti-Chanes, J.; Torres, A. High-Pressure Processing Technologies for the Pasteurization and Sterilization of Foods. Food Bioprocess Technol. 2011, 4, 969-985. [CrossRef]

16. Milani, E.A.; Alkhafaji, S.; Silva, F.V.M. Pulsed Electric Field continuous pasteurization of different types of beers. Food Control 2015, 50, 223-229. [CrossRef]

17. van Wyk, S.; Silva, F.V.M.; Farid, M.M. Pulsed electric field treatment of red wine: Inactivation of Brettanomyces and potential hazard caused by metal ion dissolution. Innov. Food Sci. Emerg. Technol. 2019, 52, 57-65. [CrossRef]

18. Puértolas, E.; López, N.; Condón, S.; Raso, J.; Álvarez, I. Pulsed electric fields inactivation of wine spoilage yeast and bacteria. Int. J. Food Microbiol. 2009, 130, 49-55. [CrossRef] [PubMed] 
19. Puértolas, E.; López, N.; Condón, S.; Álvarez, I.; Raso, J. Potential applications of PEF to improve red wine quality. Trends Food Sci. Technol. 2010, 21, 247-255. [CrossRef]

20. Saldaña, G.; Luengo, E.; Puértolas, E.; Álvarez, I.; Raso, J. Pulsed electric fields in wineries: Potential applications. In Handbook of Electroporation; Miklavcic, D., Ed.; Springer International Publishing: Berlin/Heidelberg, Germany, 2016; pp. 1-18.

21. Abca, E.E.; Akdemir Evrendilek, G. Processing of Red Wine by Pulsed Electric Fields with Respect to Quality Parameters. J. Food Process Preserv. 2014, 39, 758-767. [CrossRef]

22. García Martín, J.F.; Sun, D. Ultrasound and electric fields as novel techniques for assisting the wine ageing process: The state-of-the-art research. Trends Food Sci. Technol. 2013, 33, 40-53. [CrossRef]

23. Milani, E.A.; Silva, F.V.M. Ultrasound assisted thermal pasteurization of beers with different alcohol levels: Inactivation of Saccharomyces cerevisiae ascospores. J. Food Eng. 2017, 198, 45-53. [CrossRef]

24. Paniwnyk, L. Application of Ultrasound. In Emerging Technologies for Food Processing, 2nd ed.; Sun, D., Ed.; Academic Press: San Diego, CA, USA, 2014; pp. 271-291.

25. Delsart, C.; Grimi, N.; Boussetta, N.; Miot Sertier, C.; Ghidossi, R.; Vorobiev, E.; Mietton Peuchot, M. Impact of Pulsed Electric Field and High Voltage Electrical Discharges on red wine microbial stabilization and quality characteristics. J. Appl. Microbiol. 2015, 120, 152-164. [CrossRef]

26. Santos, M.C.; Nunes, C.; Cappelle, J.; Gonçalves, F.J.; Rodrigues, A.; Saraiva, J.A.; Coimbra, M.A. Effect of high pressure treatments on the physicochemical properties of a sulphur dioxide-free red wine. Food Chem. 2013, 141, 2558-2566. [CrossRef] [PubMed]

27. Santos, M.C.; Nunes, C.; Rocha, M.A.M.; Rodrigues, A.; Rocha, S.M.; Saraiva, J.A.; Coimbra, M.A. Impact of high pressure treatments on the physicochemical properties of a sulphur dioxide-free white wine during bottle storage: Evidence for Maillard reaction acceleration. Innov. Food Sci. Emerg. Technol. 2013, 20, 51-58. [CrossRef]

28. Alkhafaji, S.R.; Farid, M. An investigation on pulsed electric fields technology using new treatment chamber design. Innov. Food Sci. Emerg. Technol. 2007, 8, 205-212. [CrossRef]

29. Serratosa, M.P.; Marquez, A.; Lopez-Toledano, A.; Medina, M.; Merida, J. Changes in Hydrophilic and Lipophilic Antioxidant Activity in Relation to their Phenolic Composition during the Chamber Drying of Red Grapes at a Controlled Temperature. J. Agric. Food Chem. 2011, 59, 1882-1892. [CrossRef]

30. Waterhouse, A.L. Determination of Total Phenolics. In Current Protocols in Food Analytical Chemistry; John Wiley \& Sons, Inc.: Hoboken, NJ, USA, 2001.

31. Guerrero, R.F.; Cantos-Villar, E. Demonstrating the efficiency of sulphur dioxide replacements in wine: A parameter review. Trends Food Sci. Technol. 2015, 42, 27-43. [CrossRef]

32. Büyüktuncel, E.; Porgali, E.; Çolak, C. Comparison of total phenolic content and total antioxidant activity in local red wines determined by spectrophotometric methods. Food Nutr. Sci. 2014, 5, 1660-1667. [CrossRef]

33. Stratil, P.M.; Kuban, V.M.; Fojtova, J.M. Comparison of the phenolic content and total antioxidant activity in wines as determined by spectrophotometric methods. Czech J. Food Sci. 2008, 26, 242-253. [CrossRef]

34. Tao, Y.; Sun, D.; Górecki, A.; Blaszczak, W.; Lamparski, G.; Amarowicz, R.; Fornal, J.; Jelinski, T. Effects of high hydrostatic pressure processing on the physicochemical and sensorial properties of a red wine. Innov. Food Sci. Emerg. Technol. 2012, 16, 409-416. [CrossRef]

35. Delfini, C.; Conterno, L.; Carpi, G.; Rovere, P.; Tabusso, A.; Cocito, C.; Amati, A. Microbiological stabilisation of grape musts and wines by high hydrostatic pressures. J. Wine Res. 1995, 6, 143-151. [CrossRef]

36. Aadil, R.M.; Zeng, X.; Han, Z.; Sun, D. Effects of ultrasound treatments on quality of grapefruit juice. Food Chem. 2013, 141, 3201-3206. [CrossRef]

37. Sulaiman, A.; Farid, M.; Silva, F.V. Quality stability and sensory attributes of apple juice processed by thermosonication, pulsed electric field and thermal processing. Food Sci. Technol. Int. 2017, 23, 265-276. [CrossRef] [PubMed]

38. Zhang, Q.; Wang, T. Effect of ultrasound irradiation on the evolution of colour properties and major phenolic compounds in wine during storage. Food Chem. 2017, 234, 372-380. [CrossRef] [PubMed]

39. Jackson, R.S. (Ed.) Chapter 11-Sensory perception and wine assessment. In Wine Science, 4th ed.; Academic Press: San Diego, CA, USA, 2014; pp. 832-880. 